\title{
Need Analysis Development of Biological Practicum Instructions Based in Guided Inquiry for Students in Class XI
}

\author{
Rilla Elvandar ${ }^{1 *}$, Ramadhan Sumarmin $^{1}$
}

\begin{abstract}
${ }^{l}$ Biology Department, Math and Natural Science Faculty, Universitas Negeri Padang, Padang, Indonesia *Corresponding author. Email: elvandarr@yahoo.com
\end{abstract}

\begin{abstract}
In the learning practice process is guided to think scientifically while the guide is used has not directed students to think scientifically, the demands of scientific thinking are expected to improve student achievement. Therefore it is necessary to develop a practicum guide to overcome these problems, then the development of a guided inquiry-based practice guide is carried out, because in the guided inquiry process it is expected that students' scientific thinking can be elevated by the existence of certain scientific steps. Questionnaire results data obtained from students to determine what the guideline model looks like, students say that guides need to be developed with steps that are easy to understand and have attractive colors, so students are more active in laboratory activities. Based on the analysis of student needs and material analysis, it is necessary to develop apracticum guided based on guided inquiry for students in class XI .

Keywords: biology learning, development, guided inquiry, practical guide.
\end{abstract}

\section{INTRODUCTION}

Education is the process of obtaining a more human good by producing the system of values and culture, including by means of the formation of personality, skill, s erta intellectual formation[1].Efforts in changes in the development of Indonesian education have been determined by vision, mission, and strategy, so that they are able and proactively answer the challenges of the everchanging era[2].

Improved quality in Indonesia by way meninggkaatkan learning processes at all levels of education including education high school. The quality of education is seen from a number of aspects that it influences such as practical guidance. In practicum activities the participants were directly confronted with everyday events related to the concept of the lesson, both scientific conditions and manipulation through experiments . According Surajad the development of practice learning, learners are directly confronted with the phenomenon of concrete that is associated with the concept of learning so that the learning concept will be more easily digested and understood[3].

Biology is one of the subjects that carry out practicum, biology is also one of the basics that can be used in solving problems[4]. In the process of solving the problem carried out several steps that are objective, systematic, methodical, universal and empirical known as the scientific method[5].
Implementation of business activities in applying the scientific method, students both directly and in groups, active with the skills to search and explore information as a whole so that they can easily understand the concepts and principles in learning[5],in the learning process Biology learners can better understand the concept by practicum activities and basic abilities such as observation, measurement and using biological equipment.

Practical guide is very necessary in perh Turn the power off because according to Zainuddin meny Atakan in the implementation of practical need a means of $d$ late fees are relatively expensive, as well as in general implementation of the practicum takes a long time, but it is often the teachers thought that by learning in class A learner was able to understand concept [6]. Whether we realize it or not, teachers often force the will on students to understand a concept or theory that is actually difficult for them. In order to achieve practicum activities, the development of practicum activities that are clear, concise, simple and interesting is crucial to the practicum implementation.

The results of observations made by the author in class XI in April 2019, that the guideline used in La Biology Boratorium class XI SMA N 1 Sungai Rumbai not yet shaped specifically for practicum, but derived from a package book for students of class XI IPA rewritten by 
students in book bundles called Student Worksheets (LKKS), LKKS contains a collection of assignments, quizzes, Daily Tests and practical work guide. The worksheets that are sampled from the textbook are more similar to recipe books containing practicum titles, goals, tools and materials, and ways of working LKKS is used from year to year always the same and almost does not change or add information. This situation causes students to copy-paste the results of the practicum, besides that students also have difficulty understanding the language that comes from the textbook.

I also conduct an oral interview about penuntun praktikum XI in high school biology classes N 7 Padang. In this school the practicum guide used is only the teacher's sheet and the Student Worksheet (LKS) guide is rewritten by students, but this guide does not meet the standard composition of the practicum guide and is verification by prescribing model guidelines. According to Kanter., et al models prescription is not optimal in developing science process skills of students[7]. This recipe model does nothelp students a lot in developing critical thinking skills, and lacks training of students' skills in carrying out practical activities. If this continues, it is feared that there is a lack of critical thinking skills, and cannot connect various concepts in daily life.

Based on the above problems, it is necessary to develop penuntun practicum $b$ iologi class II high which facilitates the self to work scientifically. By using an inquiry approach that emphasizes students to find knowledge, ideas and information through their own efforts using scientific steps.

The inquiry approach is essentially a process of discovering something scientifically so that the study of inquiry is identical to the science process skills[8]. The process of finding scientifically what is meant is an approach that facilitates students to be critical of a problem, make provisional assumptions or hypotheses, test hypotheses, analyze data and make conclusions.

The process of implementing practical guidance guides using guided inquiry, where students are guided by full mentors such as providing problem formulations and providing procedures for overcoming problems. Guided inquiry advice is usually used for students who have not experienced learning with inquiry[9]. In free inquiry, the procedure is not provided by the teacher, so students formulate their own problems and solve their own methods of solving problems. While in free inquiry, the practicum process between guided inquiry and free inquiry. Accepting students of class XI IPA at SMAN 1 Sungai Rumbai who have not experienced learning with inquiry, the practicum guide developed will use guided inquiry.
Research conducted by Novilia [10], Koksal [11] states by using guided inquiry inquiry in the learning process. The results of this study can improve cognitive competenceand

process skills. While has conducted research under the title. Development of Guided Inquiry-Based Biology Practicum Guidelines on Digestive System Materials. The results showed that the practicum guides used for students already showed valid criteria and were suitable for use in learning[12].

Based on this background, the researcher will develop a practical guide under the title "Development of Guided Biology Practicum Guides Based on Guided Inquiry for Class XI Students in Semester II".

\section{METHODS}

This research uses a descriptive method. Descriptive research is a type of method for describing and describing real objects. Some steps are obtained as follows:

\subsection{Analysis of problems and needs}

This phase is the stage of gathering information about problems in the biology learning process and the need to develop practical practical guides for teachers and students as a medium to assist in the learning process. Data collection by means of a questionnaire that has been provided by researchers. The results of the problem and needs analysis can be used for consideration in planning and developing practical biology guides for teachers and students.

\subsection{Curriculum analysis}

Curriculum analysis is an activity of analyzing Core Competencies (KI) and Basic Competencies (KD) in Biology learning in class XI Semester II in accordance with the 2013 curriculum. This analysis aims to obtain indicators and learning objectives with the results of getting material for practical guidance in the learning process.

\subsection{Penuntu Analysis n practicum}

The practicum guidance analysis aims to see or evaluate the guide that has been used previously at SMAN 1 Sungai Rumbai. In this practical guide analysis, the first aspects are reviewed, namely the material or theoretical aspects. In this aspect reviewed the suitability of the material with the

curriculum, and the truth of the concept. Both the preliminary study and the contents cover the analysis of the cover, the preface, the table of contents, the laboratory rules, the user guide and the introduction of tools and 
practical material, in this procedure also seen the colors liked by students, work procedures, and evaluation. The third approach used, analysis of the type of approach should be able to hone the skills of students in practical activities. Fourth is the analysis of the language used, in this language analysis see whether the guide is in accordance with the rules of correct and good language, sentence structure in accordance with the abilities of students, the choice of words in accordance with student understanding, presented straightforwardly, and according to the level of students' ability to think.

\subsection{Analysis of Development of Student Needs}

Aims to find out the needs and preferences of students in the learning process. The results of this analysis can increase student enthusiasm and student curiosity by practicum guides that will be developed.

\section{RESULT AND DISCUSSION}

\subsection{Analysis of problems and needs}

Based on the results of a questionnaire that was conducted in April 2019 with Biology teachers at SMAN 1 Sungai Rumbai with Ibuk Suginah, S.Pd, it was found out that the practicum guide used in La Biology Boratorium class XI of SMA N 1 Sungai Rumbai had not yet formed a special book for practicum, but comes from textbooks for students of class XI IPA which are rewritten by students in bundles of books called Student Worksheets (LKKS), LKKS contains a collection of assignments, quizzes, Daily Tests and practical guiding work. The worksheets that are sampled from the textbook are more similar to recipe books containing practicum titles, goals, tools and materials, and ways of working .

LKKS is used from year to year always the same and almost does not change or add information. This situation causes students to copy-paste the results of the practicum, besides that students also have difficulty understanding the language that comes from the textbook. An interview conducted on April 14, 2019 revealed that Biology practicum guides did not have an approach and did not detail guiding practicum.

Based on a questionnaire that was filled out by 26 students who had done Biology lab class XI at SMAN 1 Sungai Rumbai, found several problems regarding the implementation of the practicum as follows. First, students tend to be passive and not fully involved. The results of the questionnaire showed that only $46 \%$ of students were active in practicum activities. Second, the guide has not facilitated students in working scientifically. It was revealed in the student statement that only $30 \%$ of students answered mastering the steps of the scientific method such as formulating problems, formulating hypotheses, testing hypotheses, analyzing data, and concluding. Third. Practicum guides in the eyes of students are not interesting because $73 \%$ of students stated that the guides are less attractive with color combinations. Also revealed that $38 \%$ pe nuntun practicum not have basic terori, $4 \%$ said penuntun not use discipline in carrying out practical work, as well as $27 \%$ of students stated that the language pe nuntun practicum difficult to understand.

\subsection{Curriculum analysis}

This analysis shows the performance indicators that are in accordance with the objectives of the practicum and the material contained in the practicum guide. The practicum guide has some material in the second semester of class XI including: Digestive System, Respiratory System, Expression System, Coordination System, Reproductive System, and Immune System.

Achievement Indicator Analysis in accordance with the learning objectives so that the material on the practicum guide is achieved. Practical skills are science skills. Practicum activities are never separated from the curriculum. Science process skills are cognitive and psychomotor skills used in problem solving. In the process of solving the problem carried out several steps that are objective, systematic, methodical, universal and empirical which are known by the scientific method[5].

In this study, cognitive abilities were seen by using test questions to be given to students, affective and cognitive abilities were seen by using observer questionnaires. Guided inquiry has several steps including: Orientation, Formulating Problems, Formulating Hypotheses, Collecting Data, Testing Hypotheses, and Formulating Conclusions[13].

\subsection{Guidance Analysis practicum}

Results of the practical guidance analysis that has been used previously at SMAN 1 Sungai Rumbai. In this practical guide analysis, the first aspects are reviewed, namely the material or theoretical aspects. In this aspect, the compatibility of the material with the curriculum was reviewed, it was revealed that the material in the practicum guide included the learning outcomes that had been set in rpp, but the material presented in the practicum guide was still not too deep to reach each indicator and competency achievement. The truth of the concept, in accordance with the relevant scientific discipline, is complete with the desired competency achievements, and the concepts conveyed are still relevant to the present situation.

Both the preliminary study and the contents encompass the cover analysis, preface, table of contents, laboratory rules, user guides and introduction of practical tools and materials, in this procedure also seen the colors liked by students, work procedures, and evaluations that are overall lacking because the instrument is not yet complete in the guides used and the pictures presented in the lab guides are less attractive and colorful. 
The three detectors used, in this guide the approach used has not been able to hone students' skills in practicum activities. Fourth is the analysis of the language used, in this language analysis it is seen that the guiding language is in accordance with the rules of correct and good language, sentence structure is not in accordance with the ability of students seen in the student questionnaire states it is difficult to understand the language in the practical guide, the choice of words is not with understanding students, have not been presented straightforwardly, and have not been in accordance with the level of students' ability to think.

The sum of the practical guide analysis is done by evaluating aspects where there are 29 aspects of assessment and 3 indicators, where each indicator is Good (B), Medium (S), and Less (K). final analysis of the use of practicum guides that have been used found 8 aspects with Good indicators, 7 aspects with Medium indicators and 14 aspects with indicators Less. From the results of the analysis it can be concluded that the practicum guide used is still not able to improve students' cognitive, affective and psychomotor, and therefore the need for the development of class XI biology practicum guides.

\subsection{Analysis of Development of Student Needs}

The subjects of this study were students of class XI Natural Sciences (IPA) of SMAN 1 Sungai Rumbai. The average age of students at Sungai Rumbai 1 High School 16-18 years. Based on Piaget's Theory which states that in children aged 11-18 years is the normal operation phase. Where in this phase students can think of abstracts, logically, draw conclusions, interpret and develop hypothese[14].

The analysis looks at what is in accordance with the desires of students towards practicum guides that will be developed include: $96 \%$ of students want practicum guides that have covers, table of contents, preface, instructions, rules of thumb, instructions for use, and introduction of practical tools. $100 \%$ of students want practicum guides with interesting pictures so that students more easily understand the topic to be practiced. $92 \%$ chose light green to be used as a cover for practicum guidance, with $65 \%$ of students choosing to use Time New Roman writing for writing in the practical guide to be developed, as well as students choosing a cover with 3 pictures of $85 \%, 69 \%$ and $65 \%$ respectively pictures of the heart, appendicitis, and kidneys to be used as the cover of the practicum guide.

\section{CONCLUSION}

From the analysis conducted, the results of the initial research can be stated: first the practicum guides that are in schools are still in the form of LKS which are rewritten by students called LKKS that have not been tested for Validity, Effectiveness, and Practicality. The two practicum guides that have been used do not yet have approaches so that students are less active in the learning process because learning is centered on the teacher not the student. the third guide practicum is less attractive so that students are less enthusiastic in implementing practice in the laboratory. The four students do not understand the practical guide because it uses standard language so students find it difficult to understand the instructions and material contained in the practical guide.

\section{REFERENCES}

[1] Sidik M H 2008 Pengembangan Model pembelajaran Konstruktivisme untuk Meningkatkan Pemahaman Siswa Mengenai Energi Gerak di Kelas III SD Negeri 1 Cilengkranggirang Kecamatan Pasaleman Kabupaten Cirebon Propos. Skripsi

[2] Permendiknas 2006 Standar Isi dan Standar Kompetensi Kelompok Mata Pelajaran (Jakarta: SinarGrafindo)

[3] Surajad. H 2009 Pengembangan Perangkat Percobaan Konsep Rotasi untuk Pembelajaran Fisika Di SMA dan Universitas Tesis tidak diterbitkan

[4] Tim Pengelola Biologi Dasar 1997 Diklat Kuliah Biologi Dasar (Pekanbaru: Unri Press)

[5] Trianto 2007 Model Pembelajaran Terpadu (Jakarta: Prestasi Pustaka)

[6] Zainuddin. M 1996 Panduan Praktikum dalam Mengajar di Perguruan Tinggi Bagian Empat. Program Applied Approach (Jakarta: PAUPPAI. Direktorat Jenderal Pendidikan Tinggi. Departemen Pendidikan dan Kebudayaan) pp 13-1

[7] Kanter D E, Smith H D, McKenna A, Rieger C and Linsenmeier R A 2003 Inquiry-based laboratory instruction throws Out the "Cookbook" and improves learning ASEE Annual Conference Proceedings

[8] Dewi N L, Dantes N and Sadia I W 2013 Pengaruh Model Pembelajaran Inkuiri 
Terbimbing Terhadap Sikap Ilmiah dan Hasil Belajar IPA J. Progr. Pascasarj. Univ. Pendidik. Ganesha

[9] Hosnah W M 2017 Pengaruh Model Pembelajaran Inkuiri Terbimbing Terhadap Hasil Belajar Fisika di SMA J. Pembelajaran Fis.6 No. 2 190-5

[10] Novilia L, Iskandar S M and Fajaroh F 2016 The Effectiveness Of Colloid Module Based On Guided Inquiry Approach To Increase Students' Cognitive Learning Outcomes Int. J. Educ.

[11] Koksal E A and Berberoglu G 2014 The Effect of Guided-Inquiry Instruction on 6th Grade Turkish Students' Achievement, Science Process Skills, and Attitudes Toward Science Int. J. Sci.

Educ.

[12] . M, Qurbaniah M and Kahar A P 2017 Pengembangan Penuntun Praktikum Biologi Berbasis Inkuiri Terbimbing pada Materi Sistem Pencernaan J.

BIOEDUCATION

[13] Sanjaya W 2010 Strategi Pembelajaran Berorientasi Standar Proses Pendidikan System

[14] L.E. B and S. L 1993 Private speech of learning disabled and normally achieving children in classroom academic and laboratory contexts. Child Dev. 